\title{
Proteomics Strategy for Identifying Candidate Bioactive Proteins in Complex Mixtures: Application to the Platelet Releasate
}

\author{
Roisin O'Connor, ${ }^{1}$ Lorna M. Cryan, ${ }^{2}$ Kieran Wynne, ${ }^{1}$ Andreas de Stefani, ${ }^{1}$ \\ Desmond Fitzgerald, ${ }^{2}$ Colm O'Brien, ${ }^{2}$ and Gerard Cagney ${ }^{1}$ \\ ${ }^{1}$ School of Biomolecular and Biomedical Science, Conway Institute, University College Dublin, Dublin 4, Ireland \\ ${ }^{2}$ School of Medicine and Medical Science, Conway Institute, University College Dublin, Dublin 4, Ireland \\ Correspondence should be addressed to Gerard Cagney, gcagney@gmail.com
}

Received 14 July 2009; Revised 6 October 2009; Accepted 10 November 2009

Academic Editor: Benjamin A. Garcia

Copyright (C) 2010 Roisin O'Connor et al. This is an open access article distributed under the Creative Commons Attribution License, which permits unrestricted use, distribution, and reproduction in any medium, provided the original work is properly cited.

\begin{abstract}
Proteomic approaches have proven powerful at identifying large numbers of proteins, but there are fewer reports of functional characterization of proteins in biological tissues. Here, we describe an experimental approach that fractionates proteins released from human platelets, linking bioassay activity to identity. We used consecutive orthogonal separation platforms to ensure sensitive detection: (a) ion-exchange of intact proteins, (b) SDS-PAGE separation of ion-exchange fractions and (c) HPLC separation of tryptic digests coupled to electrospray tandem mass spectrometry. Migration of THP-1 monocytes in response to complete or fractionated platelet releasate was assessed and located to just one of the forty-nine ion-exchange fractions. Over 300 proteins were identified in the releasate, with a wide range of annotated biophysical and biochemical properties, in particular platelet activation, adhesion, and wound healing. The presence of PEDF and involucrin, two proteins not previously reported in platelet releasate, was confirmed by western blotting. Proteins identified within the fraction with monocyte promigratory activity and not in other inactive fractions included vimentin, PEDF, and TIMP-1. We conclude that this analytical platform is effective for the characterization of complex bioactive samples.
\end{abstract}

\section{Introduction}

Platelets are anucleate cells that are important for haemostasis, thrombosis, and atherosclerotic disease. A number of bleeding disorders arise as a result of mutations in the genes for proteins involved in platelet aggregation. Thus, altered or deregulated platelet function underpins many diseases, and platelet proteins are potential targets for novel therapeutic agents. Previous proteomic studies of intact platelets have collectively identified hundreds of proteins using a variety of fractionation strategies including 2-dimensional electrophoresis (2DE), multidimensional chromatographic separations, membrane prefractionation techniques, and adsorption to combinatorial hexapeptide ligand libraries [1-6]. Following activation by agonists such as thrombin, platelets release storage granules and membrane vesicles that contain prothrombotic (e.g., fibrinogen), mitogenic (e.g., platelet derived growth factor), immunomodulatory (e.g., neutrophil-activating peptide 2 ), and adhesive (e.g., platelet endothelial cell adhesion molecule) proteins. A previous study from our laboratory using a MuDPIT (multidimensional protein identification technology) approach identified over 300 proteins secreted by platelets upon thrombin activation [1]. These proteins may modulate the interaction of platelets with their local cellular environment. Indeed, platelet releasate has previously been shown to induce endothelial cell permeability, endothelial cell chemotaxis, and corneal epithelial cell proliferation in cellular assays [79].

The issue of abundant (often housekeeping) proteins masking regulatory proteins of lower abundance (such as signaling proteins and cytokines) continues to be a challenging issue for proteomics particularly in the case of biofluids. Plasma has a significant dynamic range, with more than 10 orders of magnitude separating albumin concentration and the rarest measurable proteins identified to date [10]. Protein and peptide chromatography prior to MS analysis can partly address this issue. The classical example of this 
is MuDPIT, first described by Andrew Link and colleagues [11]. In the first dimension, ion-exchange chromatography (IEC) separates peptides based on ionic interactions with the solid phase and an increasing salt buffer. This is coupled to RP-HPLC to create a second dimension of separation prior to MS analysis. Complex biological samples have also been successfully separated in multiple dimensions at the protein level. For instance, a number of studies have used 1D SDSPAGE to separate proteins by molecular weight prior to MS analysis [12-15].

While modern proteomics experiments permit the analysis of hundreds to thousands of proteins in complex samples, the most powerful use of this data would combine information on protein activity with the identities of the active proteins. The emerging field of chemical proteomics [16] addresses this question elegantly for an increasing number of enzymatic functions through formation of covalent enzyme-substrate conjugates [17]. However, many higherlevel cellular functions encompassing multiple steps are not amenable to these approaches. A limited number of studies involving proteomic fractionation combined with biological assay and subsequent MS identification of active proteins have been reported [18-20]. Here we use IEC to separate the platelet releasate for subsequent assay of monocyte migratory activity. IEC relies on electrostatic interactions between the proteins and the chromatography matrix, so that fractionation primarily depends on net protein charge. We chose a scheme, incorporating both cation and anion resins, in preference to a size-based fractionation scheme because many secreted proteins are small $(<20 \mathrm{KDa})$ and so would cofractionate. We further separated the IEC fractions by SDS-PAGE, carrying out multiple ( 30) LCMS runs per IEC fraction, thus ensuring extensive coverage of the platelet releasate proteome. By correlating the presence of proteins in active fractions (and conversely by discounting the contribution of proteins detected in inactive fractions), a more focused list of active proteins could be obtained compared to those obtained from conventional proteomics approaches.

\section{Methods}

2.1. Preparation of Platelet Releasate. Plasma and washed platelet samples were prepared from $100 \mathrm{~mL}$ of blood drawn from healthy human volunteers free from analgesic medication for 10 days using a modification of the method described by Mendelsohn [21]. Following centrifugation of blood for 10 minutes at $150 \mathrm{~g}$, platelet-rich plasma (PRP) was harvested. Platelets were pelleted by centrifugation at $720 \mathrm{~g}$ for 10 minutes and subsequently resuspended in a modified HEPES buffer (JNL buffer) $(130 \mathrm{mM} \mathrm{NaCl}$, $10 \mathrm{mM}$ trisodium citrate, $9 \mathrm{mM} \mathrm{NaHCO}, 6 \mathrm{mM}$ dextrose, $0.9 \mathrm{mM} \mathrm{MgCl}, 0.81 \mathrm{mM} \mathrm{KK_{2 }} \mathrm{PO}_{4}, 10 \mathrm{mM}$ Tris $\mathrm{pH} 7.4$ ) at a concentration of $2 \times 10^{9}$ platelets $/ \mathrm{mL}$ or $2 \times 10^{8}$ platelets/mL.

Platelet suspensions were supplemented with $1.8 \mathrm{mM}$ $\mathrm{CaCl}_{2}$, incubated at $37^{\circ} \mathrm{C}$ in an aggregometer under constant stirring conditions (1100 rev/min), and stimulated with $5 \mu \mathrm{M}$ thrombin receptor-activating peptide (TRAP) for 3 minutes. Platelet releasate was isolated as previously described [1]. Briefly, platelets were removed from the releasate by two sequential centrifugal spins at $750 \mathrm{~g}$, protease inhibitor cocktail (Merck Biosciences, UK) was added, and releasate samples were stored at $-20^{\circ} \mathrm{C}$.

2.2. Ion-Exchange Chromatography. Platelet releasate samples (from $2 \times 10^{9}$ platelets $/ \mathrm{mL}$ preparations) were desalted using Zeba spin columns (Pierce, Rockford, Illinois) as per manufacturer instructions prior to ion-exchange chromatography (IEC) fractionation. Subsequently, $0.75 \mathrm{~mL}$ of desalted platelet releasate was injected onto ProPac anion and cationexchange columns (Dionex, UK) configured in series on the Ultimate TM 3000 LC system (Dionex, UK). The flow rate was set at $200 \mu \mathrm{L} / \mathrm{min}$ and fractions were collected every minute into a 96-well plate. A UV detector (wavelength of $280 \mathrm{~nm}$ ) was used to identify eluting peptides. After an initial 10-minutes equilibration, a gradient of $0.02 \mathrm{M}-0.5 \mathrm{M}$ salt was delivered to the columns by appropriate mixing of IEC buffer A $\left(20 \mathrm{mM} \mathrm{K}_{2} \mathrm{HPO}_{4} \mathrm{pH} 9.0\right)$ and IEC buffer B $\left(20 \mathrm{mM} \mathrm{K}_{2} \mathrm{HPO}_{4} \mathrm{pH} 9.0,1 \mathrm{M} \mathrm{NaCl}\right)$ over a time course of 25 -minutes. This was followed by a 5 -minute wash with IEC buffer B ("clean off") and 5-minute equilibration with IEC buffer A.

2.3. Cell Culture and Migration Assay. A monocytic leukaemia cell line, THP-1, was obtained from EACC (Salisbury, UK). Cells were grown in RPMI 1640 medium, supplemented with $10 \%$ FBS, $2 \mathrm{mM} / \mathrm{L}$ L-glutamine, $100 \mathrm{U} / \mathrm{mL}$ penicillin, and $100 \mu \mathrm{g} / \mathrm{mL}$ streptomycin. The cells were passaged every 5-7 days. All cells were maintained as a suspension culture at $37^{\circ} \mathrm{C}$ in $5 \% \mathrm{CO}_{2} / 95 \%$ ambient air. THP1 migration was measured using a Boyden chamber assay. THP- 1 cells were centrifuged at $1000 \mathrm{~g}$ and resuspended in serum-free media (SFM) at a concentration of $1 \times 10^{6}$ cells $/ \mathrm{mL}$. Of this cell suspension, $100 \mu \mathrm{L}$ was added to the upper chamber of an $8 \mu \mathrm{m}$ pore-size transwell (Corning BV, Schiphol-Rijk, The Netherlands). For the purpose of the migration assay, $2 \mu \mathrm{L}$ of three successive IEC fractions (from 1-49) were pooled and added to the lower chamber. SFM was added to a final volume of $1 \mathrm{~mL}$. A positive control of $10 \%$ FBS in SFM was used. The transwell inserts were placed into the lower chamber and incubated for 2 hours at $37^{\circ} \mathrm{C}$ in $5 \% \mathrm{CO}_{2} / 95 \%$ ambient air. The number of two populations of cells migrating to the bottom chamber was assessed, the cells migrating to the bottom chamber and adhering to the membrane and the cells migrating to the bottom chamber without adhering to the membrane. Nonmigrating cells on the upper surface of the membrane were removed by gentle scraping with a cotton bud and adherent migratory cells on the lower surface of the membrane were counted following fixation with $2.5 \%$ glutaraldehyde for 20 minutes and staining for 1 hour with crystal violet stain. The number of cells migrating and adhering to the underside of the membrane was evaluated by counting ten random non overlapping 40X fields. To assess the number of cells which migrated through the membrane but did not adhere to the membrane, the media in the lower chamber was collected and centrifuged at $1000 \mathrm{~g}$. The cell pellet was resuspended 
in $16 \mu \mathrm{L}$ PBS, $4 \mu \mathrm{L}$ trypan blue was added, and the cells were counted using a hemocytometer.

2.4. Visualisation of Fractionated Proteins. Protein from IEC fractions was methanol/chloroform precipitated [22] and separated using 4\%-20\% acrylamide gradient gels (Pierce, Rockford, Illinois) [23]. Protein gels were silver stained using a SilverSnap kit (Pierce, Rockford, Illinois).

2.5. LC-MS/MS (Liquid Chromatography-Tandem Mass Spectrometry). SDS-PAGE gel lanes were cut into 32 bands and digested in-gel with sequencing grade trypsin (Promega, Ireland) according to the method of Shevchenko et al. [15]. The resulting peptide mixtures were resuspended in $0.1 \%$ formic acid and analysed by nanoelectrospray liquid chromatography mass spectrometry (Nano-LC MS/MS). An HPLC instrument (Dionex, UK) was interfaced with an LTQ ion trap mass spectrometer (ThermoFinnigan, CA). Chromatography buffer solutions ("Buffer A", $5 \%$ acetonitrile and $0.1 \%$ formic acid; "Buffer B", $80 \%$ acetonitrile and $0.1 \%$ formic acid) were used to deliver a 60 -minute gradient (35 minutes to $45 \%$ Buffer B, 10 minutes to $90 \%$, hold for 10 minutes, 3 minutes to $5 \%$, hold for 15 minutes). A flow rate of $2 \mu \mathrm{L} / \mathrm{min}$ was used at the electrospray source. Spectra were searched using the SEQUEST algorithm against the International Protein Index (IPI) database (http://www.ebi.ac.uk/IPI/IPIhelp.html), as described previously [24]. The probability-based evaluation program, Protein Prophet, was used for filtering identifications [25].

2.6. Bioinformatic Analysis. Ontological analysis of protein identifications was performed using the GOTM website (http://babelomics2.bioinfo.cipf.es/) [26]. A hypergeometric test corrected for multiple testing (Bonferroni) was used to determine statistically significant enrichments $(P<.01)$. To analyse the range of proteins identified in this study, the predicted molecular weight and isoelectric point of each protein were obtained using the Compute $\mathrm{pL} / \mathrm{MW}$ tool from the ExPASy server (http://expasy.org/).

2.7. Western Blot. Western blot was carried out as previously described [27] with the following modifications. Equal volumes of resting and TRAP-stimulated platelet releasates were loaded into each well and separated on a $4 \%-20 \%$ acrylamide gradient gel. The primary antibody for the detection of PEDF was a rabbit polyclonal antibody ( 1 in 1000 dilution overnight at $4^{\circ} \mathrm{C}$ ) from Upstate Cell Signaling Solutions (Buckingham, UK). The primary antibody for the detection of involucrin was a mouse monoclonal antibody ( 1 in 200 dilution overnight at $4^{\circ} \mathrm{C}$ ) from Sigma (Dublin, Ireland). Anti-mouse and anti-rabbit secondary horseradish peroxidase (HRP) conjugated antibodies were obtained from Cell Signaling Technology (Danvers, MA). Peroxidase activity was detected using luminol chemiluminescent substrate from Santa Cruz Biotechnology, Inc. (Santa Cruz, CA).

\section{Results}

3.1. Strategy for Linking Biological Activities to Individual Tissue Fractions. The overall strategy is shown in Figure 1.
We used ion-exchange chromatography (IEC) to separate a complex protein mixture, proteins secreted by human platelets in response to the agonist thrombin receptoractivating peptide (TRAP), into fractions suitable for both biological analysis and identification by mass spectrometry. While strategies such as MuDPIT separate at the level of the tryptic peptide; separation at the protein level reduces sample complexity and facilitates correlation of the presence (or absence) of a protein with an observed biological function. The effect of platelet releasate on THP-1 monocyte migration was investigated to test this strategy. Addition of serum to media in the bottom of the Boyden chamber indeed stimulated migration of monocytes (data not shown), although interestingly serum stimulation did not cause the cells to adhere to the underside of the Boyden chamber membrane (Figure 2(a)). In contrast, both MCP-1 (a well-known promigratory chemokine for monocytes) and platelet releasate induced monocyte migration simultaneously caused these suspended cells to adhere to the underside of the membrane (Figure 2(a)). The effect of releasate was dose dependent (Figure 2(b)).

To identify releasate fractions with biological activity, consecutive IEC fractions were initially pooled in groups of three for the analysis of THP-1 migration. One pooled fraction, 25-27, was found to strongly induce monocyte migration (Figure 2(c)). We repeated the assay using the individual fractions 25,26 , and 27. In this second experiment, the pro-migratory activity could be localized to fraction 27 (Figure 2(d)). Data displayed in Figure 2 describes "adherent migration", that is, cells which migrated through the $8 \mu \mathrm{m}$ pores and adhered to the underside of the membrane. In order to identify the proteins present in each fraction, each lane from the SDS-PAGE gels of fractionated platelet releasate (Figure 3(a)) was divided into 32 bands, digested with trypsin, and subjected to LC-MS/MS, and the corresponding proteins were identified by database search (Supplementary Table 1 in supplementary material available online at doi: 10.1155/2010/107859). For each fraction, spectral counts (counts of tandem mass spectrometry events leading to productive protein identification), an approximate indicator of protein abundance, were calculated, and the total spectral count for all proteins in the fractions was determined (Supplementary Table 2). The top fifty proteins by spectral counts are displayed in Table 1 . The spectral counts (Figure 3(b)) and number of proteins identified (Figure 3(c)) correlate with each other, and also with the staining patterns of the proteins on the gels (Figure 3(a)). Of the 315 proteins identified, 220 were found in a unique fractions $(70 \%)$, suggesting effective IEC separation (Figure 3(d)). Abundant proteins were often found in adjacent fractions, for example, thrombospondin was most abundant in Fraction 26 but also identified in Fractions 27 and 28. Some proteins were identified in nonadjacent fractions, perhaps reflecting differential migration of protein isoforms (e.g., splicing, proteolytic cleavage, and posttranslational modification).

3.2. Biological and Biophysical Properties of Fractionated Platelet Releasate. Our analysis resulted in the high confidence identification of 315 proteins and represents an 


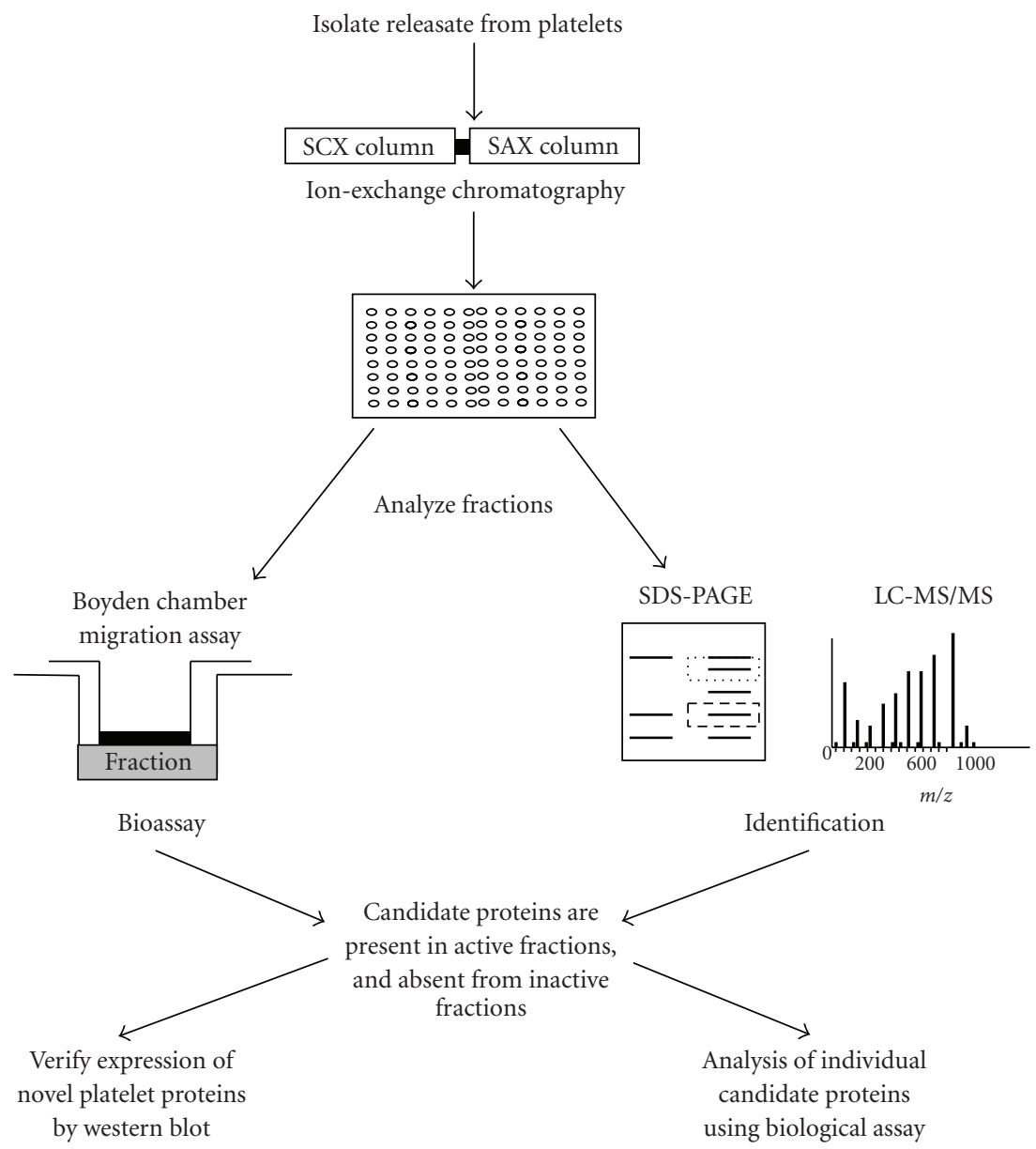

FIGURE 1: Strategy for linking function and protein identity in biofluids. An off-line MuDPIT strategy was used to identify biologically active proteins from a complex mixture. Proteins released from platelets were separated by SCX/SAX chromatography. The collected fractions were analyzed for pro-migratory activity using a monocyte Boyden chamber assay. The fractions were separated in the second dimension by SDSPAGE, and gel lanes were excised and the proteins were digested with trypsin. The resulting peptides were separated by RP-HPLC, ionized by electrospray, and subjected to MS/MS to identify potential pro-migratory proteins.

extensive proteomic coverage of platelet releasate. The identified proteins demonstrated an extensive array of annotated biophysical properties as are evidenced by the wide range of PI and molecular weights predicted for the identifications (Figure 4(b)), suggesting that the method introduced no strong bias against any category of protein. Similarly, proteins with a wide range of annotated activities were identified. The frequency of different functional annotations within the released platelet proteins was compared to the expected frequency based on all human proteins annotated in the Gene Ontology (GO) database using the GOTM program [26]. Hemostasis, blood coagulation, and wound healing were identified as being overrepresented biological processes, as well as molecular functions such as actin binding, protein binding, and calcium ion binding $(P<.01)$ (Figure 4(a)). GO levels between 2 and 5 were used to avoid overgeneral and overspecific functions. Many of these enriched functions appear to be relevant to potential endocrine platelet functions, for instance, "hemostasis", "wound healing", and "coagulation", while others may be relevant to the platelet activation response ("platelet activation", "localization", "purine nucleotide binding", and "calcium binding").

3.3. Investigation of Active Fraction. Thirty-two proteins were found in Fraction 27, the only fraction that stimulated monocyte migration (Table 2). Of these proteins, six were not found in any other fraction in our study. These proteins included tissue inhibitor of metalloproteinase 1 (TIMP-1), vimentin, and pigment epithelium-derived growth factor (PEDF). Spectral counts, functions, and information on their identification in other fractions are listed for all fraction 27 proteins in Table 2. The bold areas highlight those proteins that are only found in Fraction 27. The identified proteins were compared to datasets from previous studies of platelet proteins to determine whether the identified proteins had been previously identified in platelets $[1,2,5,6,27-31]$. The presence of two novel platelet proteins, PEDF and involucrin (see Supplementary Table 1 for full details), was confirmed by immunoblotting (Figure 5). PEDF was identified at the expected mass of approximately $50 \mathrm{kDa}$ in platelet releasate preparations with additional heavier 


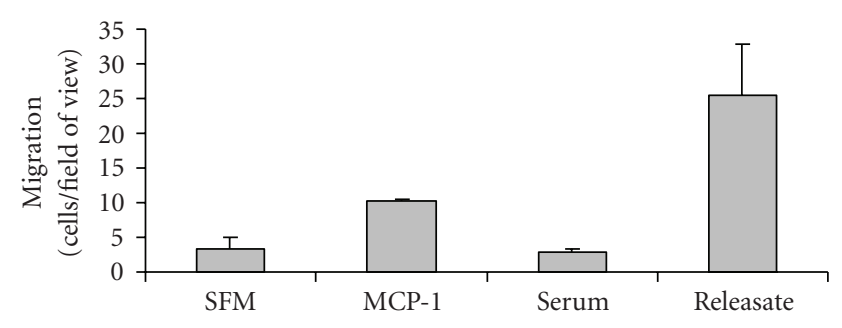

(a)

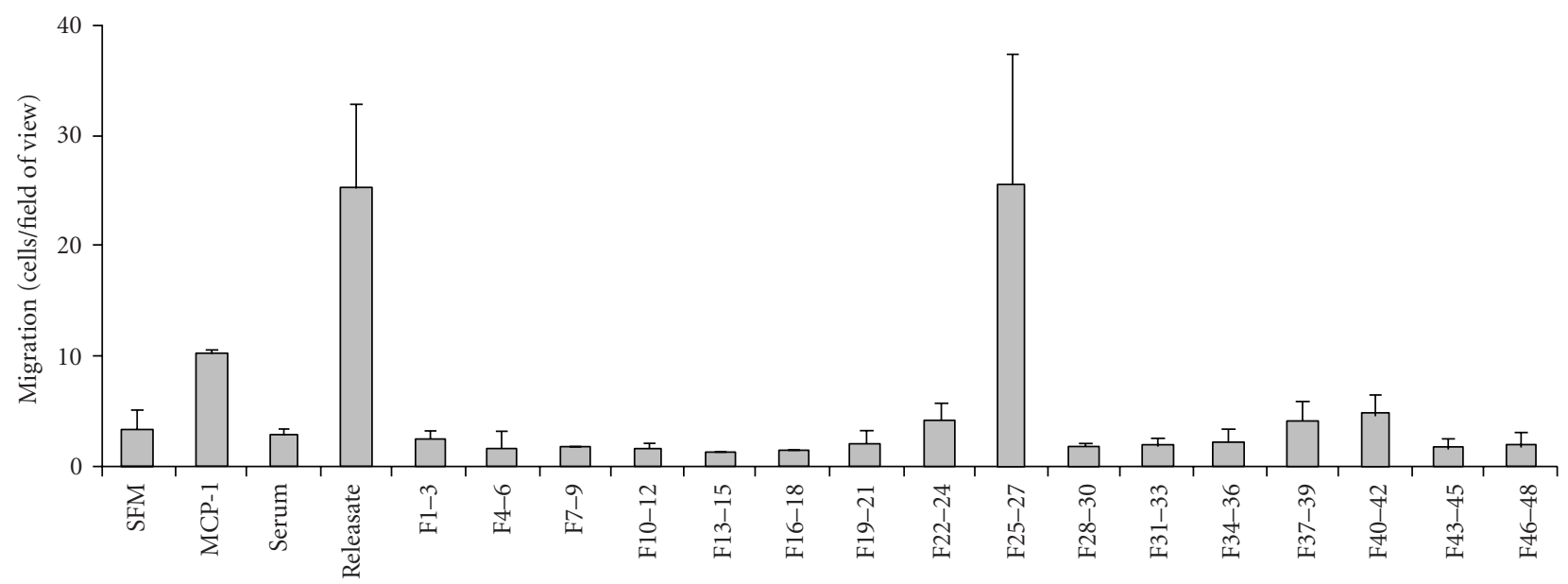

(c)

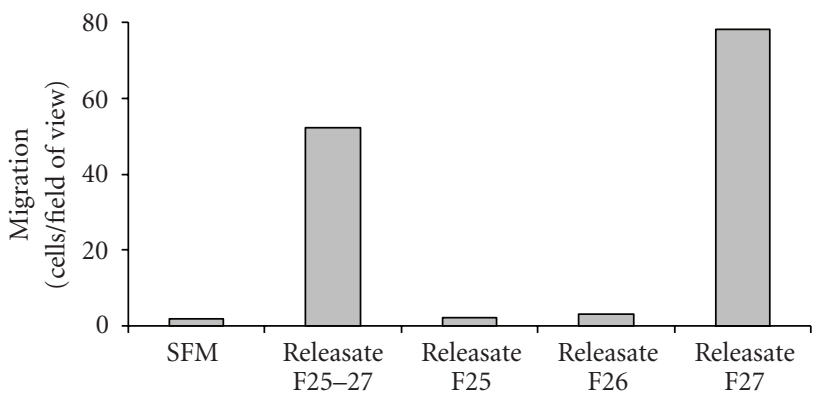

(d)

FIgURE 2: A pro-migratory effect identified in unfractionated and fractionated platelet releasate. THP-1 monocyte cell migration was measured using a Boyden chamber assay over 2 hours. (a) Assessment of migrated cells adhering to the underside of the membrane in response to platelet releasate, Serum (10\%), and MCP-1 $(100 \mathrm{ng} / \mathrm{mL}) . N=3$; (b) Adherent migrated THP-1 cells in response to 10,25 or $100 \mu \mathrm{L}$ platelet releasate; $N=3$. (c) Fractions were pooled in groups of three and added to serum-free media (SFM) in the bottom chamber. Positive controls include MCP-1 and unfractionated platelet releasate; $N=3$. (d) Localisation of the pro-migratory effect of Fractions $25-27$ to an individual fraction. Each fraction $(2 \mu \mathrm{L})$ was added to serum-free media in the bottom chamber of a separate well and compared with the combination of Fractions $25-27$ ( $2 \mu \mathrm{L}$ of each fraction). TRAP $=$ thrombin receptor-activating peptide. $N=3$. The average number of migrated cells adhering to the underside of the membrane was calculated from ten $40 \mathrm{X}$ fields of view.

bands also detected (Figure 5(a)). Previous studies have identified PEDF at $50 \mathrm{kDa}$ with additional bands at $66 \mathrm{kDa}$ and $76 \mathrm{kDa}$ in Y79 cell lysates using this antibody. PEDF was found to a greater extent in TRAP-stimulated platelet releasate compared to resting/unstimulated releasate. The highest band $(76 \mathrm{kDa})$ was also present in the resting releasate from four different individual donors. Involucrin was identified in TRAP-stimulated platelet releasates at a mass of approximately $120 \mathrm{kDa}$ (Figure 5(b)).

\section{Discussion}

One aim of proteomics is to address biological questions through the identification and characterization of proteins en mass. In this study, we developed an approach to separate a complex biological mixture using orthogonal separation methods. At the protein level, we used IEC followed by SDS-PAGE, while at the peptide level, reverse phase chromatography preceded MS analysis. We successfully applied 


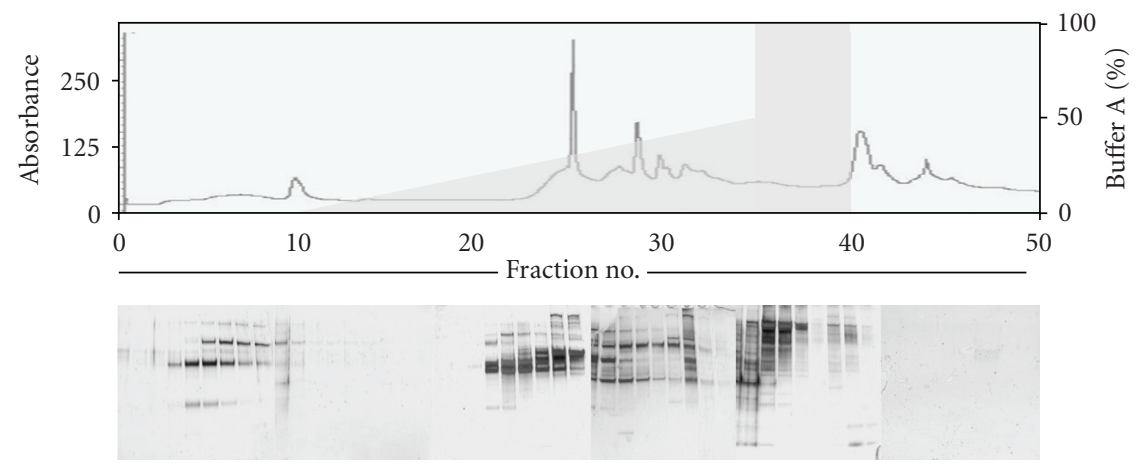

(a)

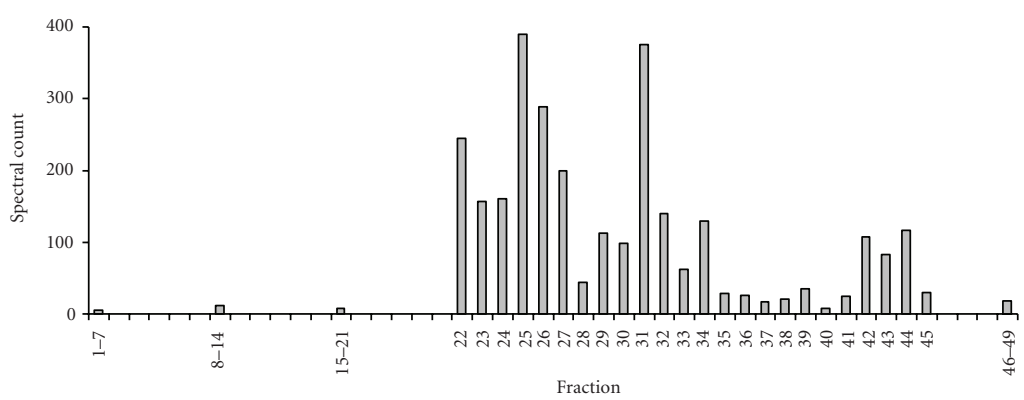

(b)

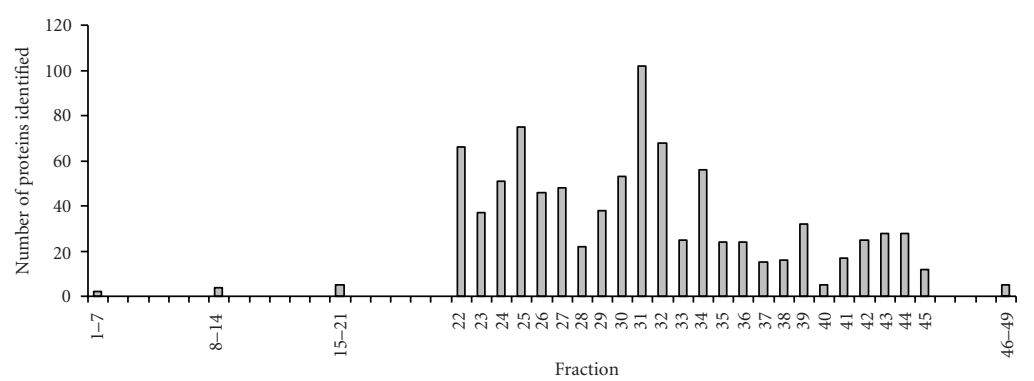

(c)

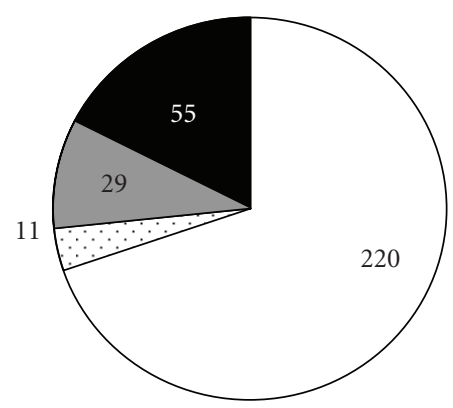

(d)

FIgURE 3: Fractionation of the platelet releasate by ion-exchange chromatography. (a) From each releasate fraction collected, $80 \mu \mathrm{L}$ was precipitated to remove salt, resuspended in $10 \mu \mathrm{L}$ of Laemmli buffer, and separated by MW on 4\%-20\% acrylamide gels. Silver-stained gels are displayed below corresponding sections of the ion-exchange UV detected chromatogram. A UV wavelength of $280 \mathrm{~nm}$ was used to detect eluting peptides. (b) The number of spectra detected in each fraction following LC MS/MS of tryptically digested 1D gel pieces. (c) The number of proteins identified in each fraction using SEQUEST with a score greater than 0.9. (d) Representation of the number and proportion of proteins in a single fraction, two adjacent fractions; two nonadjacent fractions, or more than two fractions. 


\begin{tabular}{|c|c|c|c|c|c|c|c|c|c|}
\hline \multicolumn{5}{|c|}{ GO biological process } & \multicolumn{5}{|c|}{ Molecular function } \\
\hline $\begin{array}{l}\text { GO } \\
\text { level }\end{array}$ & & observed & expected & $P$-value & $\begin{array}{l}\mathrm{GO} \\
\text { level }\end{array}$ & & observed & expected & $P$-value \\
\hline 4 & regulation of body fluids & 14 & 1.88 & $5.01647 \mathrm{E}-09$ & 3 & protein binding & 100 & 82.04 & .008838235 \\
\hline 5 & hemostasis & 13 & 1.68 & $1.12792 \mathrm{E}-08$ & 3 & nucleotide binding & 52 & 33.63 & .000751555 \\
\hline 4 & blood coagulation & 12 & 1.57 & $4.88352 \mathrm{E}-08$ & 4 & purine nucleotide binding & 48 & 28.78 & .000228825 \\
\hline 4 & coagulation & 12 & 1.61 & $6.33109 \mathrm{E}-08$ & 5 & adenyl nucleotide binding & 39 & 23.35 & .000946115 \\
\hline 5 & wound healing & 12 & 1.75 & $1.67416-07$ & 5 & calcium ion binding & 34 & 14.89 & $5.28281 \mathrm{E}-06$ \\
\hline 4 & $\begin{array}{l}\text { physiological response to } \\
\text { wounding }\end{array}$ & 19 & 5.88 & $6.93829 \mathrm{E}-06$ & 4 & cytoskeletal protein binding & 21 & 5.88 & $4.74782 \mathrm{E}-07$ \\
\hline 4 & response to wounding & 19 & 6.06 & $1.06834 \mathrm{E}-05$ & 5 & actin binding & 17 & 4.07 & $7.06132 \mathrm{E}-07$ \\
\hline 3 & response to external stimulus & 23 & 8.48 & $1.35735 \mathrm{E}-05$ & 3 & enzyme inhibitor activity & 16 & 4.12 & $3.93645 \mathrm{E}-06$ \\
\hline 3 & localization & 68 & 43.15 & $4.023 \mathrm{E}-05$ & 5 & guanyl nucleotide binding & 13 & 5.85 & .006071454 \\
\hline 4 & response to unfolded protein & 7 & 0.98 & $4.94329 \mathrm{E}-05$ & 4 & carrier activity & 12 & 4.98 & .004386769 \\
\hline 4 & response to protein stimulus & 7 & 0.98 & $4.94329 \mathrm{E}-05$ & 4 & protease inhibitor activity & 11 & 2.39 & $2.79983 \mathrm{E}-05$ \\
\hline 4 & establishment of localization & 67 & 42.74 & $5.55917 \mathrm{E}-05$ & 5 & $\begin{array}{l}\text { endopeptidase inhibitor } \\
\text { activity }\end{array}$ & 11 & 2.37 & $2.6147 \mathrm{E}-05$ \\
\hline 4 & platelet activation & 4 & 0.31 & .000205689 & 3 & $\begin{array}{l}\text { structural constituent of } \\
\text { cytoskeleton }\end{array}$ & 9 & 1.59 & $2.93143 \mathrm{E}-05$ \\
\hline 4 & tissue development & 12 & 3.69 & .000335856 & 3 & antigen binding & 8 & 1.01 & $6.94074 \mathrm{E}-06$ \\
\hline 3 & response to stress & 28 & 14.03 & .000359514 & 3 & unfolded protein binding & 7 & 1.87 & .002692475 \\
\hline 3 & $\begin{array}{l}\text { response to chemical } \\
\text { stimulus }\end{array}$ & 17 & 6.71 & .000415494 & 4 & protein binding bridging & 5 & 1.26 & .008431955 \\
\hline 3 & cell adhesion & 23 & 11.26 & .000908494 & 3 & vitamin binding & 5 & 1.29 & .009440404 \\
\hline 4 & muscle contraction & 9 & 2.55 & .001043693 & 4 & $\begin{array}{l}\text { translation elongation } \\
\text { factor activity }\end{array}$ & 4 & 0.33 & .000285878 \\
\hline 3 & cellular localization & 22 & 10.83 & .001255793 & 4 & $\begin{array}{l}\text { intramolecular } \\
\text { oxidoreductase activity }\end{array}$ & 4 & 0.72 & .005532653 \\
\hline 3 & cell differentiation & 21 & 10.27 & .001492504 & 3 & $\begin{array}{l}\text { structural constituent of } \\
\text { muscle }\end{array}$ & 4 & 0.59 & .002785384 \\
\hline
\end{tabular}

(a)

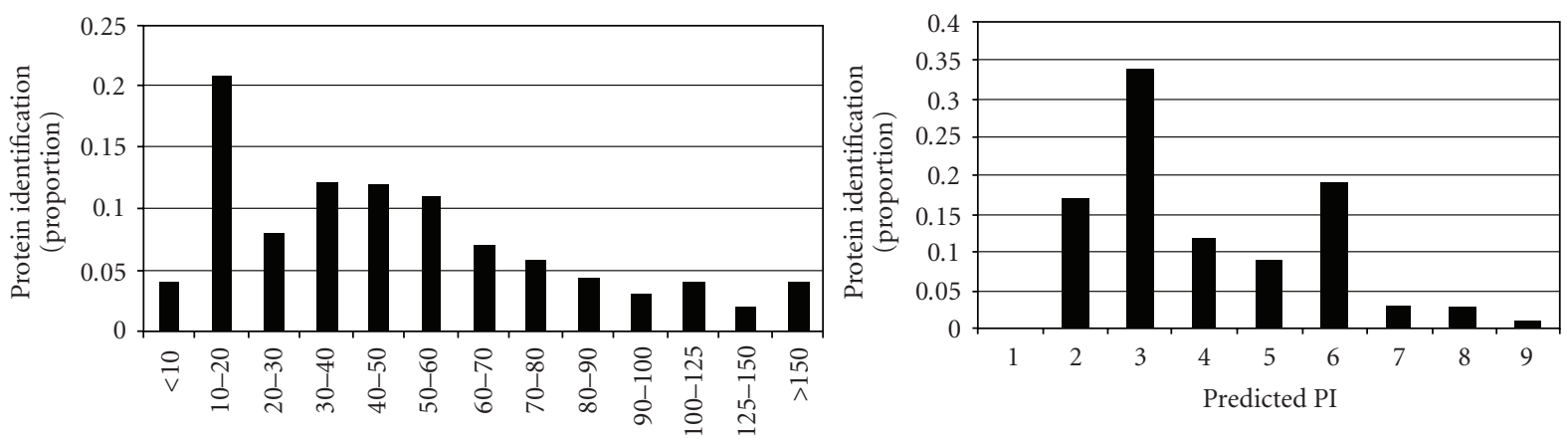

Predicted MW $(\mathrm{kDa})$

(b)

FIGURE 4: Bioinformatic analysis of the fractionated platelet releasate. (a) Gene ontology (GO) terms found to be significantly enriched in the experimental dataset of platelet releasate proteins ("Observed") in comparison to a reference dataset of human proteins ("Expected") along with the GO level associated with each individual ontological term. (b) The range of molecular weights (left panel) and isoelectric points (right panel) of proteins identified in this study.

protein fractions separated by IEC to a biological assay of monocyte cell migration. The denaturing conditions of gel-based protein separation largely preclude subsequent functional analysis of the proteins. However, a recently developed nondenaturing 2DE method used for the analysis of the Shewanella oneidensis microbial proteome may have applications for functional analysis of separated protein mixtures in the future [32]. The enzymatic activity of malate dehydrogenases from this bacterium was retained and identified within the polyacrylamide gel following 2DE [32].

In total, 315 unique proteins were identified in this analysis of platelet releasate. Proteins which we have previously identified such as fibrinogen, albumin, thrombospondin, haemoglobin, platelet factor 4 , platelet basic protein, and 
TABLE 1: Most abundant 50 proteins determined in the study (fractions 1-49).

\begin{tabular}{|c|c|c|c|c|c|c|c|c|c|c|c|c|c|c|c|c|c|c|c|c|c|c|c|c|c|c|c|c|c|}
\hline Accession number & Description & $1-7$ & $8-14$ & $15-21$ & 22 & 23 & 24 & 25 & 26 & 27 & 28 & 29 & 30 & 31 & 32 & 33 & 34 & 35 & 36 & 37 & 38 & 39 & 40 & 41 & 42 & 43 & 44 & 45 & $46-49$ \\
\hline \begin{tabular}{|l|} 
IPI00745872.2 \\
\end{tabular} & Isoform 1 of serum albumin precursor & - & - & - & - & 11 & 28 & 180 & 73 & 274 & 55 & - & - & 12 & - & - & \begin{tabular}{|l|l|}
- & \\
\end{tabular} & - & - & - & - & - & - & - & 37 & - & - & - & - \\
\hline IPI00022434.4 & Uncharacterized protein alb & - & - & - & 28 & 39 & 82 & 157 & 32 & 78 & 21 & 20 & 22 & 42 & 29 & 4 & 11 & 1 & 4 & 5 & 1 & 1 & 3 & 5 & 38 & 13 & - & - & - \\
\hline IPI00008669.4 & Uncharacterized protein ensp00000257935 & - & - & - & 43 & 75 & - & 15 & 32 & - & - & 26 & 69 & 7 & 57 & - & \begin{tabular}{|l|}
- \\
\end{tabular} & - & - & - & - & - & - & - & - & - & - & - & - \\
\hline IPI00796364.1 & 51 kda protein & - & - & - & 22 & 52 & - & 14 & 23 & - & - & 10 & 55 & - & 62 & - & 5 & - & - & - & - & - & - & - & - & - & - & - & - \\
\hline IPI00021439.1 & Actin; cytoplasmic 1 & - & - & - & 33 & 14 & - & 51 & 21 & 20 & 22 & 39 & - & 13 & 12 & 3 & - & - & - & - & - & - & - & - & - & - & - & - & - \\
\hline IPI00745872.2 & Serum albumin (cell growth inhibiting protein 42 ) & - & - & - & - & - & - & - & - & - & - & - & - & - & - & - & - & - & - & - & - & - & - & - & - & - & 134 & 58 & - \\
\hline IPI00298497.3 & Fibrinogen beta chain precursor & - & - & - & - & 59 & 30 & 13 & 30 & 18 & 2 & - & - & - & - & - & - & - & - & - & - & - & - & - & - & - & 27 & - & - \\
\hline IPI00022434.3 & Alb protein & 14 & 11 & 8 & - & - & - & - & - & - & - & - & - & - & - & - & - & - & - & - & - & - & - & - & - & - & 46 & 60 & 29 \\
\hline IPI00021891.5 & Isoform gamma-b of fibrinogen gamma chain precursor & - & - & - & - & 66 & 28 & 17 & 26 & 14 & - & - & - & - & - & - & - & - & - & - & - & - & - & - & - & - & - & - & - \\
\hline IPI00027547.2 & Dermcidin precursor & - & 1 & 2 & 2 & 7 & 24 & 6 & 2 & 15 & 6 & 10 & 7 & 31 & 10 & & 5 & - & - & - & - & - & - & 11 & - & - & - & 2 & - \\
\hline IPI00884222.1 & Similar to keratin, type 1 cytoskeletal 10 & - & - & - & - & - & - & - & - & 62 & - & - & - & - & 54 & - & - & - & - & - & - & - & - & - & - & - & - & - & - \\
\hline IPI00021841.1 & Apolipoprotein a-i precursor & - & - & - & - & - & - & 15 & - & 3 & - & - & - & 1 & 4 & - & 2 & - & - & - & - & - & - & - & - & - & 67 & 9 & - \\
\hline IPI00013933.2 & Isoform dpi of desmoplakin & - & - & - & 27 & - & 4 & - & - & 5 & - & 2 & 6 & 32 & 8 & - & - & - & - & - & - & - & - & - & - & - & - & - & - \\
\hline IPI00784154.1 & 60 kda heat shock protein; mitochondrial precursor & - & - & - & 60 & 2 & - & - & - & - & - & - & - & - & 2 & 4 & 14 & - & - & - & - & - & - & - & - & - & - & - & - \\
\hline IPI00296099.6 & Thrombospondin-1 precursor & - & - & - & - & - & - & - & 37 & 32 & 10 & - & - & - & - & - & - & - & - & - & - & - & - & - & - & - & - & - & - \\
\hline IPI00016801.1 & Glutamate dehydrogenase 1 ; mitochondrial precursor & - & - & - & 28 & 28 & - & - & - & - & - & - & - & - & 16 & 3 & - & - & - & - & - & - & - & - & - & - & - & - & - \\
\hline IPI00021885.1 & Isoform 1 of fibrinogen alpha chain precursor & - & - & - & - & 19 & 12 & 17 & 19 & 5 & - & - & - & - & - & - & 1 & - & - & - & - & - & - & - & - & - & - & - & - \\
\hline IPI00478003.1 & Alpha-2-macroglobulin precursor & - & - & - & - & 3 & - & 9 & - & 13 & - & - & - & - & - & - & - & - & - & - & - & - & - & - & - & - & 46 & - & - \\
\hline IPI00022445.1 & Platelet basic protein precursor & - & - & - & - & 2 & 5 & 3 & 11 & 12 & 2 & 2 & 8 & 3 & 4 & 3 & 2 & - & - & - & - & - & - & - & - & - & - & - & - \\
\hline IPI00419424.3 & \begin{tabular}{|l|} 
Igkv1-5 protein \\
\end{tabular} & - & - & - & - & 1 & 2 & 7 & - & 2 & - & - & - & 3 & - & - & - & - & - & - & - & - & - & - & 2 & - & 33 & 1 & - \\
\hline IPI00021885.1 & Splice isoform 1 of fibrinogen alpha chain precursor & - & - & - & - & - & - & - & - & - & - & - & - & - & - & - & - & - & - & - & - & - & - & - & - & - & 42 & 9 & - \\
\hline IPI00217960.1 & Isoform 2 of camp-dependent PK; alpha-catalytic subunit & - & - & - & 17 & 12 & - & - & - & - & - & - & - & - & 9 & - & - & - & - & - & - & - & - & - & - & - & - & - & - \\
\hline IPI00019502.3 & Myosin-9 & - & - & - & - & - & - & 19 & - & - & 1 & 18 & - & - & - & - & - & - & - & - & - & - & - & - & - & - & - & - & - \\
\hline IPI00164623.4 & Complement c3 precursor & - & - & - & - & - & - & - & - & - & - & - & - & - & - & - & - & - & - & - & - & - & - & - & - & - & 37 & - & - \\
\hline IPI00022446.1 & Platelet factor 4 precursor & - & - & - & - & - & - & - & - & - & - & - & - & - & - & - & - & - & - & - & - & - & - & - & 1 & 6 & 7 & 22 & - \\
\hline IPI00022463.1 & Serotransferrin precursor & - & - & - & - & - & - & - & - & - & - & - & - & 3 & - & - & - & - & - & - & - & - & - & - & 3 & - & 30 & - & - \\
\hline IPI00453473.6 & Histone h4 & - & - & - & 2 & 4 & - & 4 & 3 & 3 & - & - & 5 & 6 & 6 & - & - & - & - & - & - & - & - & - & - & - & - & - & - \\
\hline IPI00021536.1 & Calmodulin-like protein 5 & - & - & - & - & - & 5 & 12 & - & - & - & - & - & 7 & 8 & - & - & - & - & - & - & - & - & - & - & - & - & - & - \\
\hline IPI00298994.6 & Uncharacterized protein tln1 & - & - & - & - & - & - & - & 31 & - & - & - & - & - & - & - & - & - & - & - & - & - & - & - & - & - & - & - & - \\
\hline IPI00219221.3 & Galectin-7 & - & - & - & 8 & 3 & 2 & 6 & - & - & - & - & - & 8 & 1 & - & - & - & - & - & - & - & - & - & - & - & - & - & - \\
\hline IPI00384938.1 & Hypothetical protein dkfzp686n02209 & - & - & - & - & - & - & - & - & - & - & - & - & - & - & - & - & - & - & - & - & - & - & - & - & - & 26 & - & - \\
\hline IPI00783987.2 & Complement c3 precursor (fragment) & - & - & - & 4 & - & - & 6 & - & 15 & - & - & - & - & - & - & - & - & - & - & - & - & - & - & - & - & - & - & - \\
\hline IPI00015614.3 & Isoform a of trypsin-3 precursor & - & - & - & - & - & - & - & - & - & - & - & - & - & - & - & 2 & - & 3 & 5 & 7 & - & 4 & - & 3 & - & - & - & - \\
\hline IPI00431645.1 & Hp protein & - & - & - & - & 5 & 9 & 10 & - & - & - & - & - & - & - & - & - & - & - & - & - & - & - & - & - & - & - & - & - \\
\hline IPI00302592.2 & Filamin a; alpha isoform 1 & - & - & - & - & - & - & - & 23 & - & - & - & - & - & - & - & - & - & - & - & - & - & - & - & - & - & - & - & - \\
\hline IPI00004358.4 & Glycogen phosphorylase; brain form & - & - & - & 19 & - & - & - & - & - & - & - & - & - & 2 & 2 & - & - & - & - & - & - & - & - & - & - & - & - & - \\
\hline IPI00022204.2 & Serpin b3 & - & - & - & - & - & 5 & 9 & - & - & - & - & - & 9 & - & - & - & - & - & - & - & - & - & - & - & - & - & - & - \\
\hline IPI00027462.1 & Protein s100-a9 & - & - & - & - & - & 4 & 16 & - & - & - & - & - & 2 & - & - & - & - & - & - & - & - & - & - & - & - & - & - & - \\
\hline IPI00021891.5 & Splice isoform gamma-b of fibrinogen gamma chain precursor & - & - & - & - & - & - & - & - & - & - & - & - & - & - & - & - & - & - & - & - & - & - & - & - & - & 21 & - & - \\
\hline IPI00154742.6 & Iglc1 protein & - & - & - & - & - & - & - & - & - & - & - & - & - & - & - & - & - & - & - & - & - & - & - & - & - & 20 & - & - \\
\hline IPI00291175.7 & Isoform 1 of vinculin & - & - & - & - & - & - & - & 20 & - & - & - & - & - & - & - & - & - & - & - & - & - & - & - & - & - & - & - & - \\
\hline IPI00553177.1 & Alpha-1-antitrypsin precursor & - & - & - & - & - & - & - & - & - & - & - & - & - & - & - & - & - & - & - & - & - & - & - & - & - & 18 & - & - \\
\hline IPI00025753.1 & Desmoglein-1 precursor & - & - & - & 5 & - & 3 & - & - & - & - & - & 2 & 6 & 2 & - & - & - & - & - & - & - & - & - & - & - & - & - & - \\
\hline IPI00026314.1 & Isoform 1 of gelsolin precursor & - & - & - & - & - & - & - & 3 & 14 & - & - & - & - & - & - & - & - & - & - & - & - & - & - & - & - & - & - & - \\
\hline IPI00017601.1 & Ceruloplasmin precursor & - & - & - & 1 & - & - & - & - & 15 & - & - & - & - & - & - & - & - & - & - & - & - & - & - & - & - & - & - & - \\
\hline IPI00003935.6 & Histone h2b type 2 -e & - & - & - & 5 & 2 & - & - & - & 1 & - & - & - & 6 & - & - & - & - & - & - & - & - & - & - & - & - & - & - & - \\
\hline IPI00383164.1 & Snc66 protein & - & - & - & - & - & - & - & - & - & - & - & - & - & - & - & - & - & - & - & - & - & - & - & - & - & 14 & - & - \\
\hline IPI00008603.1 & Actin; aortic smooth muscle & - & 3 & 2 & - & - & - & - & - & - & 2 & - & - & 4 & - & 2 & - & - & - & - & - & - & - & - & - & - & - & - & - \\
\hline IPI00010951.2 & Epiplakin & - & - & - & 5 & - & - & 2 & - & - & - & - & - & 6 & - & - & - & - & - & - & - & - & - & - & - & - & - & - & - \\
\hline IPI00654755.3 & Hemoglobin subunit beta & - & - & - & - & 1 & 4 & 3 & 5 & - & - & - & - & - & - & - & - & - & - & - & - & - & - & - & - & - & - & - & - \\
\hline
\end{tabular}

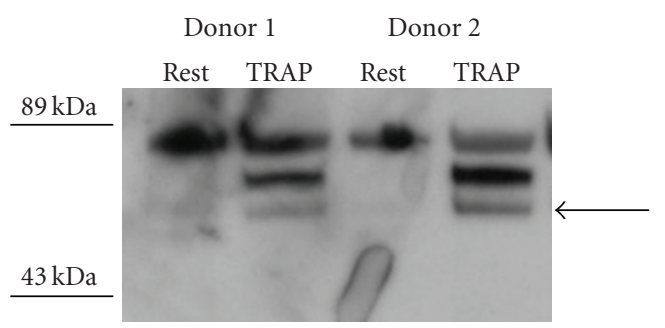

(a)

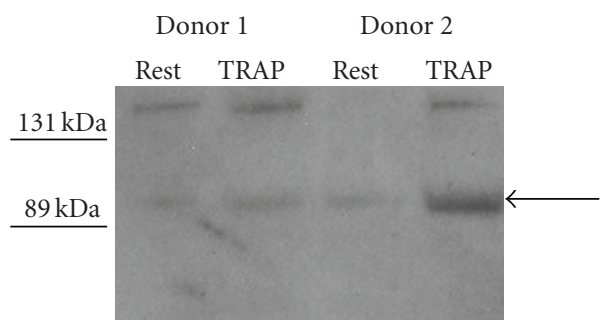

(b)

FIGURE 5: Western blot validation of novel platelet proteins. $30 \mu \mathrm{L}$ of resting and TRAP-stimulated platelet releasate were separated on a 4\%-20\% gradient SDS-PAGE gel and probed for PEDF and involucrin. (a) PEDF was detected as a band at approximately $50 \mathrm{kDa}$, with additional heavier bands that may represent glycosylated forms of the protein. (b) Involucrin was detected at the expected molecular weight as a band resolving at approximately $120 \mathrm{kDa}$. The locations of molecular weight markers are also indicated. These proteins were identified in TRAP-stimulated platelet releasates from 4 individual donors. Images displayed are representative of the 4 individual donors. $\mathrm{R}$ $=$ Resting/unstimulated platelet releasate $\mathrm{T}=\mathrm{TRAP}$-stimulated platelet releasate. 
Table 2: Proteins identified in Fraction 27.

\begin{tabular}{|c|c|c|c|c|c|}
\hline IPI no. & Protein name & $\begin{array}{l}\text { Spectral } \\
\text { count }\end{array}$ & $\begin{array}{l}\text { Other fractions } \\
\text { where protein was } \\
\text { found }\end{array}$ & Description & $\begin{array}{l}\text { Previously } \\
\text { found in } \\
\text { platelets }\end{array}$ \\
\hline IPI00745872.2 & $\begin{array}{l}\text { Isoform } 1 \text { of serum } \\
\text { albumin precursor }\end{array}$ & 274 & $23-26,28,31,42$ & Serum albumin & Yes \\
\hline IPI00022434.4 & $\begin{array}{l}\text { Uncharacterized protein } \\
\text { alb }\end{array}$ & 78 & $22-26,28-43$ & Albumin protein & Yes \\
\hline IPI00021439.1 & Actin, cytoplasmic 1 & 20 & $\begin{array}{l}22-23,25-26 \\
28-29,31-33\end{array}$ & $\begin{array}{l}\text { Highly conserved } \\
\text { cytoskeletal protein involved } \\
\text { in cell motility }\end{array}$ & Yes \\
\hline IPI00298497.3 & $\begin{array}{l}\text { Fibrinogen beta chain, } \\
\text { precursor }\end{array}$ & 18 & $23-26,28,44$ & $\begin{array}{l}\text { Yields monomers that } \\
\text { polymerize fibrin and act as } \\
\text { a cofactor in platelet } \\
\text { aggregation }\end{array}$ & Yes \\
\hline IPI00021891.5 & $\begin{array}{l}\text { Isoform gamma-b of } \\
\text { fibrinogen gamma chain } \\
\text { precursor }\end{array}$ & 14 & $23-26$ & $\begin{array}{l}\text { Yields monomers that } \\
\text { polymerize fibrin and act as } \\
\text { a cofactor in platelet } \\
\text { aggregation }\end{array}$ & Yes \\
\hline IPI00027547.2 & Dermcidin precursor & 15 & $\begin{array}{l}8-26,28-32,34 \\
41,45\end{array}$ & $\begin{array}{l}\text { Antimicrobial activity and } \\
\text { survival promoting peptide } \\
\text { for neurons }\end{array}$ & \\
\hline IPI00884222.1 & $\begin{array}{l}\text { Similar to keratin, type } 1 \\
\text { cytoskeletal } 10\end{array}$ & 62 & 32 & $\begin{array}{l}\text { Heterotetramer of two type I } \\
\text { and two type II keratins }\end{array}$ & \\
\hline IPI00021841.1 & $\begin{array}{l}\text { Apolipoprotein a-i } \\
\text { precursor }\end{array}$ & 3 & $\begin{array}{l}25,31-32,34 \\
44-45\end{array}$ & $\begin{array}{l}\text { Participates in reverse } \\
\text { transport of cholesterol from } \\
\text { tissues to the liver }\end{array}$ & \\
\hline IPI00013933.2 & $\begin{array}{l}\text { Isoform dpi of } \\
\text { desmoplakin }\end{array}$ & 5 & $22,24,29-32$ & $\begin{array}{l}\text { High molecular weight } \\
\text { protein of desmosomes }\end{array}$ & \\
\hline IPI00296099.6 & $\begin{array}{l}\text { Thrombospondin-1 } \\
\text { precursor }\end{array}$ & 32 & 26,28 & $\begin{array}{l}\text { Adhesive glycoprotein that } \\
\text { mediates cell-to-cell and } \\
\text { cell-to-matrix interactions }\end{array}$ & Yes \\
\hline IPI00021885.1 & $\begin{array}{l}\text { Isoform } 1 \text { of fibrinogen } \\
\text { alpha chain precursor }\end{array}$ & 5 & $23-26,34$ & $\begin{array}{l}\text { Cofactor in platelet } \\
\text { aggregation and yield } \\
\text { monomers that polymerize } \\
\text { into fibrin }\end{array}$ & Yes \\
\hline IPI00478003.1 & $\begin{array}{l}\text { Alpha-2-macroglobulin } \\
\text { precursor }\end{array}$ & 13 & $23,25,44$ & Protease inhibitor & \\
\hline IPI00022445.1 & $\begin{array}{l}\text { Platelet basic protein } \\
\text { precursor }\end{array}$ & 12 & $23-26,28-34$ & $\begin{array}{l}\text { Precursor for a number of } \\
\text { peptides with antimicrobial } \\
\text { (TC-1 and TC-2), } \\
\text { chemoattractant, and } \\
\text { stimulation of DNA } \\
\text { synthesis activity }\end{array}$ & Yes \\
\hline IPI00419424.3 & Igkv1-5 protein & 2 & $\begin{array}{l}23-25,31,42, \\
44-45\end{array}$ & Immunoglobulin & \\
\hline IPI00453473.6 & Histone h4 & 3 & $\begin{array}{l}22-23,25-26 \\
30-32,34,36\end{array}$ & $\begin{array}{l}\text { Core component of } \\
\text { nucleosomes playing a } \\
\text { central role in DNA repair, } \\
\text { replication, and } \\
\text { transcription }\end{array}$ & \\
\hline IPI00783987.2 & $\begin{array}{l}\text { Complement c3 precursor } \\
\text { (fragment) }\end{array}$ & 15 & 22,25 & $\begin{array}{l}\text { Involved in activation of the } \\
\text { complement system and } \\
\text { local inflammation }\end{array}$ & \\
\hline IPI00026314.1 & $\begin{array}{l}\text { Isoform } 1 \text { of gelsolin } \\
\text { precursor }\end{array}$ & 14 & 26 & $\begin{array}{l}\text { Calcium-regulated, } \\
\text { actin-modulating protein }\end{array}$ & Yes \\
\hline IPI00022434.4 & $\begin{array}{l}\text { Uncharacterized protein } \\
\text { alb. }\end{array}$ & 78 & $22-26,28-43$ & $\begin{array}{l}\text { Uncharacterized albumin } \\
\text { protein }\end{array}$ & Yes \\
\hline
\end{tabular}


TABle 2: Continued.

\begin{tabular}{|c|c|c|c|c|c|}
\hline IPI no. & Protein name & $\begin{array}{l}\text { Spectral } \\
\text { count }\end{array}$ & $\begin{array}{l}\text { Other fractions } \\
\text { where protein was } \\
\text { found }\end{array}$ & Description & $\begin{array}{l}\text { Previously } \\
\text { found in } \\
\text { platelets }\end{array}$ \\
\hline IPI00017601.1 & Ceruloplasmin precursor & 15 & 22 & $\begin{array}{l}\text { Glycoprotein involved in } \\
\text { iron transport across cell } \\
\text { membrane }\end{array}$ & \\
\hline IPI00382606.1 & $\begin{array}{l}\text { Factor vii active site mutant } \\
\text { immunoconjugate }\end{array}$ & 4 & 45 & $\begin{array}{l}\text { Initiates extrinsic pathway of } \\
\text { blood coagulation }\end{array}$ & \\
\hline IPI00154742.6 & Igl@protein & 2 & $24-25,31$ & Immunoglobulin & \\
\hline IPI00550991.3 & $\begin{array}{l}\text { Alpha-1-antichymotrypsin } \\
\text { precursor }\end{array}$ & 6 & 44 & $\begin{array}{l}\text { Inhibits neutrophil cathepsin } \\
\mathrm{G} \text { and mast cell chymase }\end{array}$ & \\
\hline IPI00025252.1 & $\begin{array}{l}\text { Protein disulfide-isomerase } \\
\text { a3 precursor }\end{array}$ & 4 & 26 & $\begin{array}{l}\text { Catalyses the rearrangement } \\
\text { of S-S bonds in proteins }\end{array}$ & Yes \\
\hline IPI00022431.1 & $\begin{array}{l}\text { Alpha-2-hs-glycoprotein } \\
\text { precursor }\end{array}$ & 3 & 44 & $\begin{array}{l}\text { Secreted protein, part of the } \\
\text { fetuin family, may be } \\
\text { involved in differentiation }\end{array}$ & Yes \\
\hline IPI00032292.1 & $\begin{array}{l}\text { Metalloproteinase inhibitor } \\
1 \text { precursor }\end{array}$ & 3 & & $\begin{array}{l}\text { Complexes with } \\
\text { metalloproteinases and } \\
\text { irreversibly inactivates them }\end{array}$ & Yes \\
\hline IPI00555812.4 & $\begin{array}{l}\text { Vitamin d-binding protein } \\
\text { precursor }\end{array}$ & 1 & 23,44 & $\begin{array}{l}\text { Multifunctional protein } \\
\text { found in many body fluids } \\
\text { and on the surface of various } \\
\text { cell types }\end{array}$ & Yes \\
\hline IPI00179709.4 & $\begin{array}{l}\text { Isoform } 1 \text { of tubulin } \\
\text { alpha- } 3 \mathrm{c} / \mathrm{d} \text { chain }\end{array}$ & 2 & & $\begin{array}{l}\text { Major constituent of } \\
\text { microtubules }\end{array}$ & \\
\hline IPI00006114.4 & $\begin{array}{l}\text { Proliferation-inducing } \\
\text { protein 35/PEDF }\end{array}$ & 2 & & $\begin{array}{l}\text { Induces neuronal } \\
\text { differentiation and inhibits } \\
\text { angiogenesis }\end{array}$ & Yes \\
\hline IPI00739464.1 & $\begin{array}{l}\text { Similar to cytoplasmic } \\
\text { beta-actin }\end{array}$ & 1 & 31 & $\begin{array}{l}\text { Highly conserved } \\
\text { cytoskeletal protein involved } \\
\text { in cell motility }\end{array}$ & Yes \\
\hline IPI00414860.6 & 60 s ribosomal protein $137 \mathrm{a}$ & 1 & & $\begin{array}{l}\text { Ribosomal protein } \\
\text { containing a zinc finger } \\
\text { domain, expressed in many } \\
\text { cell types }\end{array}$ & Yes \\
\hline IPI00020996.3 & $\begin{array}{l}\text { Insulin-like growth } \\
\text { factor-binding protein } \\
\text { complex acid labile chain } \\
\text { precursor }\end{array}$ & 1 & & $\begin{array}{l}\text { Secreted protein involved in } \\
\text { protein complexes with } \\
\text { insulin-like growth factor } \\
\text { family }\end{array}$ & \\
\hline IPI00418471.6 & Vimentin & 1 & & $\begin{array}{l}\text { Class III intermediate } \\
\text { filament protein found in } \\
\text { many nonepithelial cells }\end{array}$ & Yes \\
\hline
\end{tabular}

actin binding proteins were well represented [1]. While it cannot be discounted that some of these proteins may be residual serum proteins or proteins derived from cellular debris, the identifications detailed in this study are in agreement with previous publications from our laboratory and further afield (see $[1,2,4,27,33-36]$ ).

We also report the identification of proteins which have previously been implicated in neuronal exocytosis such as calmodulin-like protein 3 in Fraction 25 [37] and pleckstrin and sec7 domain protein in Fractions 22 and 26, respectively, [38]. Pigment epithelium-derived factor (PEDF) was also identified in the platelet releasate by mass spectrometric methods and its presence was validated by western blot. PEDF is a potent inhibitor of angiogenesis in the eye [39] and has also been detected in plasma and serum [40, 41]. Interestingly, a recent study suggests that pro- and antiangiogenic proteins within the platelet may be separated into distinct subsets of alpha granules which are differentially released depending on the agonist [42]. We also confirmed the presence of involucrin, a protein found as a component of scaffolding in the cell envelope of stratified epithelium, in the platelet releasate by western blotting. This protein has not 
been previously identified in nonepithelial cell types to the best of our knowledge.

Previous studies in our laboratory established that the platelet releasate had a much greater pro-migratory effect on THP-1 monocytes than on human arterial smooth muscle cells or human retinal endothelial cells (data not shown). The use of ion-exchange fractionation enabled us to locate the pro-migratory activity of the platelet releasate to just one of 49 Fractions. Candidate proteins which may be responsible for the monocyte pro-migratory activity of Fraction 27 include tissue inhibitor of metalloproteinase 1 (TIMP-1) and proliferation-inducing protein 35 (PEDF). Future studies will focus on identifying the potential pro-migratory protein, or proteins, in Fraction 27 by using neutralizing antibodies in our cell-based assay, against some of the identified proteins. A decrease in the biological activity of the candidate protein due to the presence of a neutralizing antibody would further support its pro-migratory effect in our cell assay.

However it is also possible, despite the extensive protein separation methods used, that the protein responsible for the migratory activity is a small protein of low abundance which may never be captured by mass spectrometry. Antibody arrays of growth factors and cytokines may also assist in the identification of the pro-migratory protein secreted by platelets. Using this technology we have previously shown that PDGF, angiogenin, RANTES, and many other cytokines and growth factors are secreted by platelets following thrombin activation [27]. These proteins were not identified in any fraction in the current mass spectrometric study of the platelet releasate. Investigation of the contribution of some likely pro-migratory cytokine candidates within the platelet releasate has ruled out certain proteins in terms of monocyte migration. Anti-RANTES neutralizing antibodies had no effect on platelet releasate-induced THP-1 monocyte migration (data not shown). It seems unlikely that MCP-1 is the chemokine responsible for platelet releasate-induced THP-1 migration because $100 \mathrm{ng} / \mathrm{mL}$ MCP- 1 induced a much lower level of THP-1 migration than TRAP-stimulated platelet releasate.

Both collagen I and collagen IV were identified in Fraction 27 but not in any other fraction, and previous studies in our laboratory have shown a pro-migratory effect of collagen I on arterial smooth muscle cells, so we also investigated the effect of these extracellular matrix proteins on THP-1 migration. However, no evidence of a pro-migratory effect was observed (data not shown). In addition, the possibility that a group of proteins rather than an individual protein in Fraction 27 contributed to the pro-migratory effect can not be discounted without further investigation.

In summary, the approach outlined in the current study facilitated the penetration of the platelet releasate proteome to a sufficient degree to increase the number of low-abundance identifications. This in turn highlighted candidate proteins responsible for platelet releasate induced monocyte cell migration which merit further targeted functional analysis. The method described here could be equally applied to other secretory systems and biological situations involving the functional analysis of secreted proteins from one cell type on another cell function.

\section{Acknowledgments}

The authors thank anonymous reviewers for helpful suggestions and the Mass Spectrometry Resource at the UCD Conway Institute. This study was funded by Science Foundation of Ireland and the National Council for the Blind of Ireland. The first and the second authors contributed equally to this manuscript.

\section{References}

[1] J. A. Coppinger, G. Cagney, S. Toomey, et al., "Characterization of the proteins released from activated platelets leads to localization of novel platelet proteins in human atherosclerotic lesions," Blood, vol. 103, no. 6, pp. 2096-2104, 2004.

[2] A. Garcia, S. Prabhakar, C. J. Brock, et al., "Extensive analysis of the human platelet proteome by two-dimensional gel electrophoresis and mass spectrometry," Proteomics, vol. 4, no. 3, pp. 656-668, 2004.

[3] K. Gevaert, M. Goethals, L. Martens, et al., "Exploring proteomes and analyzing protein processing by mass spectrometric identification of sorted N-terminal peptides," Nature Biotechnology, vol. 21, pp. 566-569, 2003.

[4] P. Gravel, J. C. Sanchez, C. Walzer, et al., "Human blood platelet protein map established by two-dimensional polyacrylamide gel electrophoresis," Electrophoresis, vol. 16, no. 7, pp. 1152-1159, 1995.

[5] J. Moebiust, R. P. Zahedi, U. Lewandrowski, C. Berger, U. Walter, and A. Sickmann, "The human platelet membrane proteome reveals several new potential membrane proteins," Molecular and Cellular Proteomics, vol. 4, no. 11, pp. 17541761, 2005.

[6] L. Guerrier, S. Claverol, F. Fortis, et al., "Exploring the platelet proteome via combinatorial, hexapeptide ligand libraries," Journal of Proteome Research, vol. 6, no. 11, pp. 4290-4303, 2007.

[7] L. Liu, D. Hartwig, S. Harloff, et al., "Corneal epitheliotrophic capacity of three different blood-derived preparations," Investigative Ophthalmology and Visual Science, vol. 47, no. 6, pp. 2438-2444, 2006.

[8] J. S. Rhee, M. Black, U. Schubert, et al., "The functional role of blood platelet components in angiogenesis," Thrombosis and Haemostasis, vol. 92, no. 2, pp. 394-402, 2004.

[9] A. Brill, H. Elinav, and D. Varon, "Differential role of platelet granular mediators in angiogenesis," Cardiovascular Research, vol. 63, no. 2, pp. 226-235, 2004.

[10] L. Anderson and N. G. Anderson, "High resolution twodimensional electrophoresis of human plasma proteins," Proceedings of the National Academy of Sciences of the United States of America, vol. 74, no. 12, pp. 5421-5425, 1977.

[11] A. J. Link, J. Eng, D. M. Schieltz, et al., "Direct analysis of protein complexes using mass spectrometry," Nature Biotechnology, vol. 17, no. 7, pp. 676-682, 1999.

[12] J. M. Asara, X. Zhang, B. Zheng, et al., "In-gel stable isotope labeling for relative quantification using mass spectrometry," Nature Protocols, vol. 1, no. 1, pp. 46-51, 2006.

[13] J. E. Froehlich, C. G. Wilkerson, W. K. Ray, et al., "Proteomic study of the Arabidopsis thaliana chloroplastic envelope membrane utilizing alternatives to traditional two-dimensional electrophoresis," Journal of Proteome Research, vol. 2, no. 4, pp. 413-425, 2003.

[14] K. Kaneko, H. Ando, T. Seo, Y. Ono, T. Tainaka, and W. Sumida, "Proteomic analysis of protein plugs: causative agent 
of symptoms in patients with choledochal cyst," Digestive Diseases and Sciences, vol. 52, no. 8, pp. 1979-1986, 2007.

[15] A. Shevchenko, M. Wilm, O. Vorm, and M. Mann, "Mass spectrometric sequencing of proteins from silver-stained polyacrylamide gels," Analytical Chemistry, vol. 68, no. 5, pp. 850-858, 1996.

[16] A. Leitner and W. Lindner, "Chemistry meets proteomics: the use of chemical tagging reactions for MS-based proteomics," Proteomics, vol. 6, no. 20, pp. 5418-5434, 2006.

[17] C. M. Salisbury and B. F. Cravatt, "Activity-based probes for proteomic profiling of histone deacetylase complexes," Proceedings of the National Academy of Sciences of the United States of America, vol. 104, no. 4, pp. 1171-1176, 2007.

[18] G. S. Magalhaes, M. Lopes-Ferreira, I. L. M. Junqueira-deAzevedo, et al., "Natterins, a new class of proteins with kininogenase activity characterized from Thalassophryne nattereri fish venom," Biochimie, vol. 87, no. 8, pp. 687-699, 2005.

[19] H. Wang, X. Yang, G. C. Bowick, et al., "Identification of proteins bound to a thioaptamer probe on a proteomics array," Biochemical and Biophysical Research Communications, vol. 347, no. 3, pp. 586-593, 2006.

[20] J. Biarc, I. S. Nguyen, A. Pini, et al., "Carcinogenic properties of proteins with pro-inflammatory activity from Streptococcus infantarius (formerly S. bovis)," Carcinogenesis, vol. 25, no. 8, pp. 1477-1484, 2004.

[21] M. E. Mendelsohn, Y. Zhu, and S. O’Neill, “The 29-kDa proteins phosphorylated in thrombin-activated human platelets are forms of the estrogen receptor-related $27-\mathrm{kDa}$ heat shock protein," Proceedings of the National Academy of Sciences of the United States of America, vol. 88, no. 24, pp. 11212-11216, 1991.

[22] D. Wessel and U. I. Flugge, "A method for the quantitative recovery of protein in dilute solution in the presence of detergents and lipids," Analytical Biochemistry, vol. 138, no. 1, pp. 141-143, 1984.

[23] U. K. Laemmli, "Cleavage of structural proteins during the assembly of the head of bacteriophage T4," Nature, vol. 227, no. 5259, pp. 680-685, 1970.

[24] J. R. Yates III, J. K. Eng, A. L. McCormack, and D. Schieltz, "Method to correlate tandem mass spectra of modified peptides to amino acid sequences in the protein database," Analytical Chemistry, vol. 67, no. 8, pp. 1426-1436, 1995.

[25] A. I. Nesvizhskii, A. Keller, E. Kolker, and R. Aebersold, "A statistical model for identifying proteins by tandem mass spectrometry," Analytical Chemistry, vol. 75, no. 17, pp. 46464658, 2003.

[26] B. Zhang, D. Schmoyer, S. Kirov, and J. Snoddy, "GOTree Machine (GOTM): a web-based platform for interpreting sets of interesting genes using gene ontology hierarchies," $B M C$ Bioinformatics, vol. 5, article 16, 2004.

[27] J. A. Coppinger, R. O'Connor, K. Wynne, et al., "Moderation of the platelet releasate response by aspirin," Blood, vol. 109, no. 11, pp. 4786-4792, 2007.

[28] B. Walkowiak, M. Kaminska, W. Okroj, et al., "The blood platelet proteome is changed in UREMIC patients," Platelets, vol. 18, no. 5, pp. 386-388, 2007.

[29] D. M. Maynard, H. F. Heijnen, M. K. Horne, J. G. White, and W. A. Gahl, "Proteomic analysis of platelet $\alpha$-granules using mass spectrometry," Journal of Thrombosis and Haemostasis, vol. 5, no. 9, pp. 1945-1955, 2007.

[30] L. Martens, P. Van Damme, J. Van Damme, et al., "The human platelet proteome mapped by peptide-centric proteomics: a functional protein profile," Proteomics, vol. 5, pp. 3193-3204, 2005.
[31] B. A. Garcia, D. M. Smalley, H. Cho, J. Shabanowitz, K. Ley, and D. F. Hunt, "The platelet microparticle proteome," Journal of Proteome Research, vol. 4, no. 5, pp. 1516-1521, 2005.

[32] C. S. Giometti, T. Khare, S. L. Tollaksen, et al., "Analysis of the Shewanella oneidensis proteome by two-dimensional gel electrophoresis under nondenaturing conditions," Proteomics, vol. 3, pp. 777-785, 2003.

[33] V. Dubernard, B. B. Arbeille, M. B. Lemesle, and C. Legrand, "Evidence for an $\alpha$-granular pool of the cytoskeletal protein $\alpha$ actinin in human platelets that redistributes with the adhesive glycoprotein thrombospondin-1 during the exocytotic process," Arteriosclerosis, Thrombosis, and Vascular Biology, vol. 17, no. 10, pp. 2293-2305, 1997.

[34] D. V. Gnatenko, J. J. Dunn, S. R. McCorkle, D. Weissmann, P. L. Perrotta, and W. F. Bahou, "Transcript profiling of human platelets using microarray and serial analysis of gene expression," Blood, vol. 101, no. 6, pp. 2285-2293, 2003.

[35] G. O. Gogstad, I. Hagen, R. Korsmo, and N. O. Solum, "Characterization of the proteins of isolated human platelet alpha-granules. Evidence for a separate alpha-granule-pool of the glycoproteins IIb and IIIa," Biochim Biophys Acta, vol. 670, no. 2, pp. 150-162, 1981.

[36] J. P. McRedmond, S. D. Park, D. F. Reilly, J. A. Coppinger, P. B. Maguire, D. C. Shields, and D. J. Fitzgerald, "Integration of proteomics and genomics in platelets: a profile of platelet proteins and platelet-specific genes," Molecular and Cellular Proteomics, vol. 3, no. 2, pp. 133-144, 2004.

[37] S. Quetglas, C. Iborra, N. Sasakawa, et al., "Calmodulin and lipid binding to synaptobrevin regulates calcium-dependent exocytosis," EMBO Journal, vol. 21, no. 15, pp. 3970-3979, 2002.

[38] J. Polgar, S. H. Chung, and G. L. Reed, "Vesicle-associated membrane protein 3 (VAMP-3) and VAMP-8 are present in human platelets and are required for granule secretion," Blood, vol. 100, no. 3, pp. 1081-1083, 2002.

[39] D. W. Dawson, O. V. Volpert, P. Gillis, et al., "Pigment epithelium-derived factor: a potent inhibitor of angiogenesis," Science, vol. 285, no. 5425, pp. 245-248, 1999.

[40] S. V. Petersen, Z. Valnickova, and J. J. Enghild, "Pigmentepithelium-derived factor (PEDF) occurs at a physiologically relevant concentration in human blood: purification and characterization," Biochemical Journal, vol. 374, no. 1, pp. 199206, 2003.

[41] A. J. Jenkins, S. X. Zhang, K. G. Rowley, et al., "Increased serum pigment epithelium-derived factor is associated with microvascular complications, vascular stiffness and inflammation in type 1 diabetes 1," Diabetic Medicine, vol. 24, no. 12, pp. 1345-1351, 2007.

[42] J. E. Italiano Jr., J. L. Richardson, S. Patel-Hett, et al., "Angiogenesis is regulated by a novel mechanismml: pro- and anti-angiogenic proteins are organized into separate platelet $\{\alpha\}$-granules and differentialy released," Blood, 2007. 

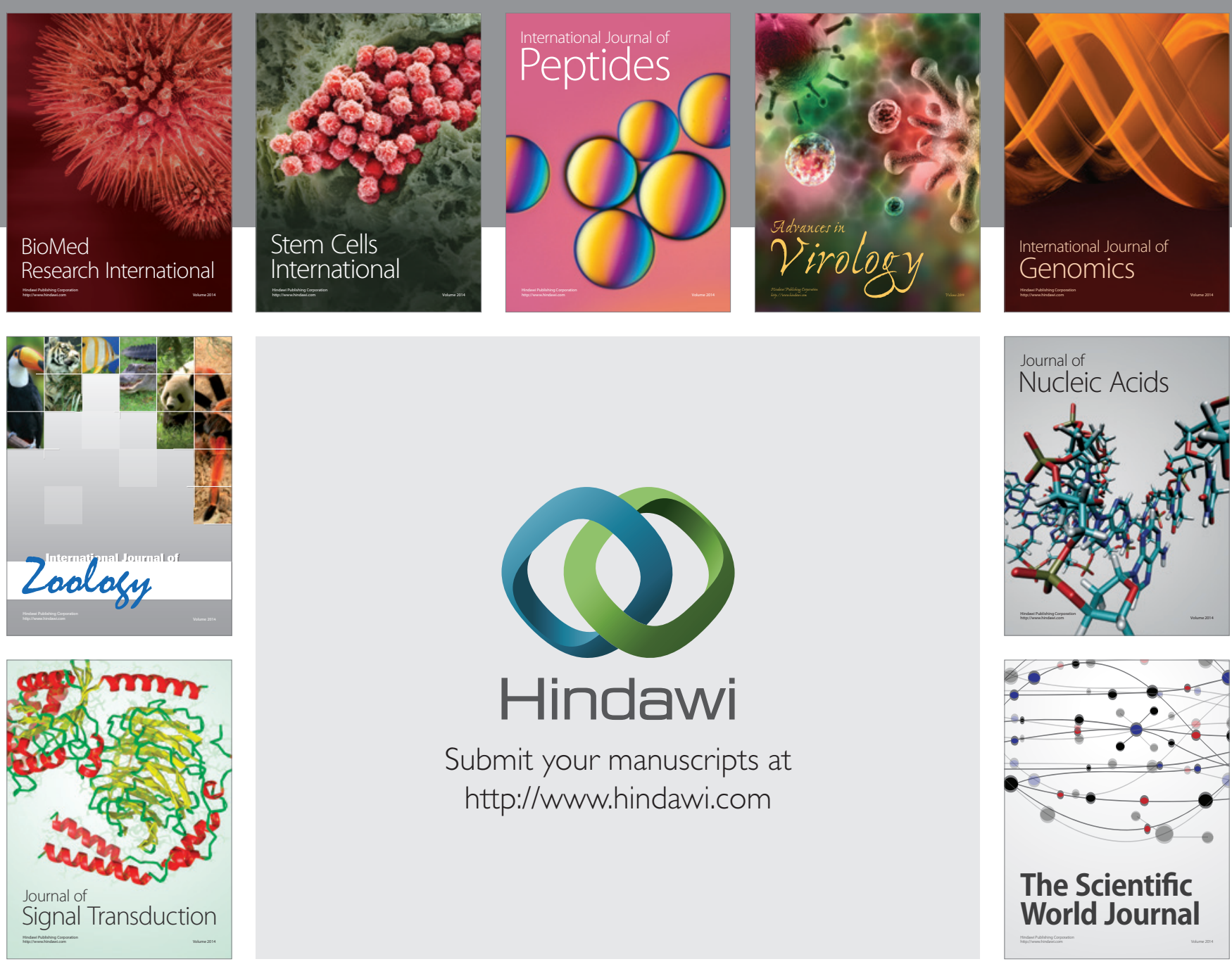

Submit your manuscripts at

http://www.hindawi.com
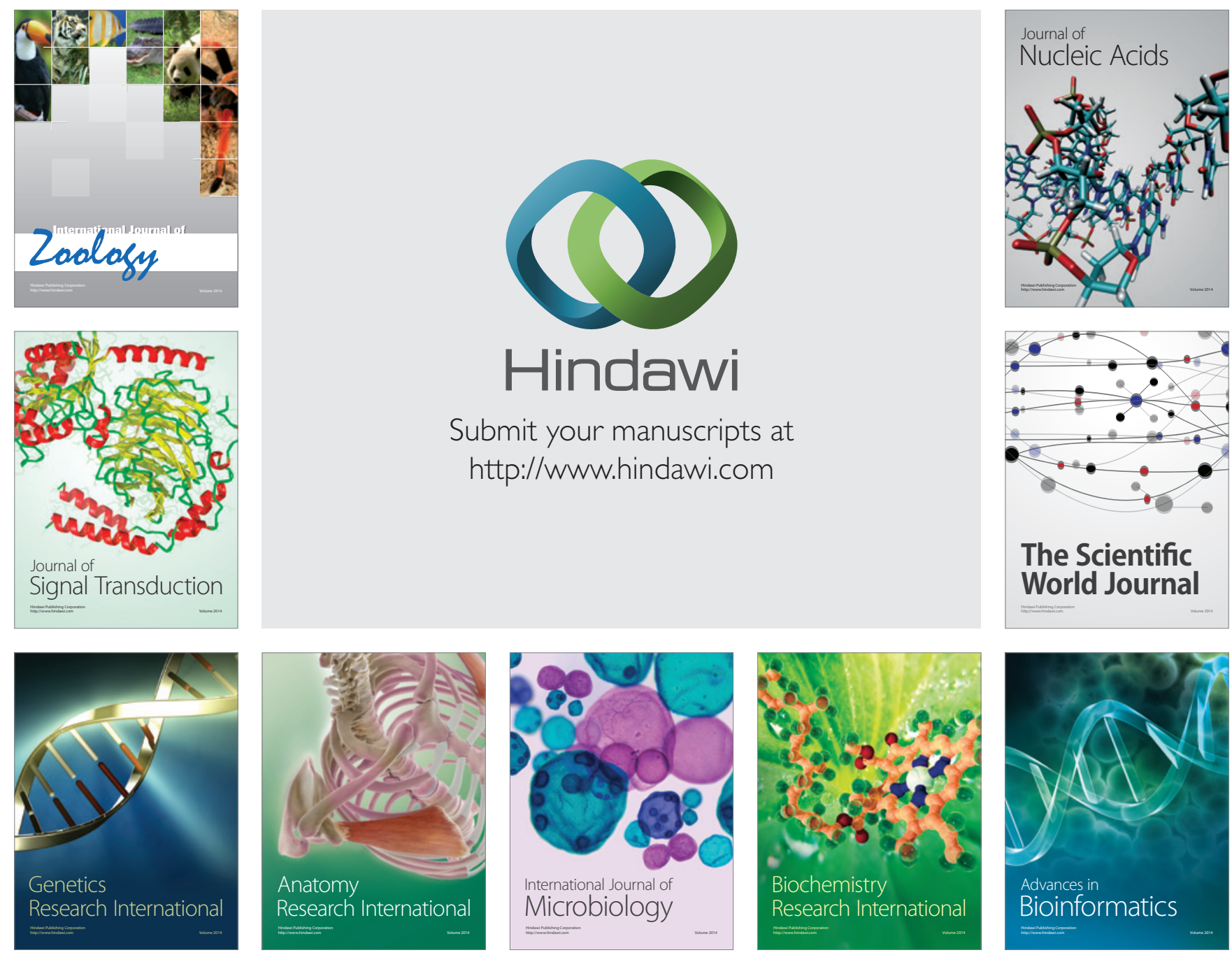

The Scientific World Journal
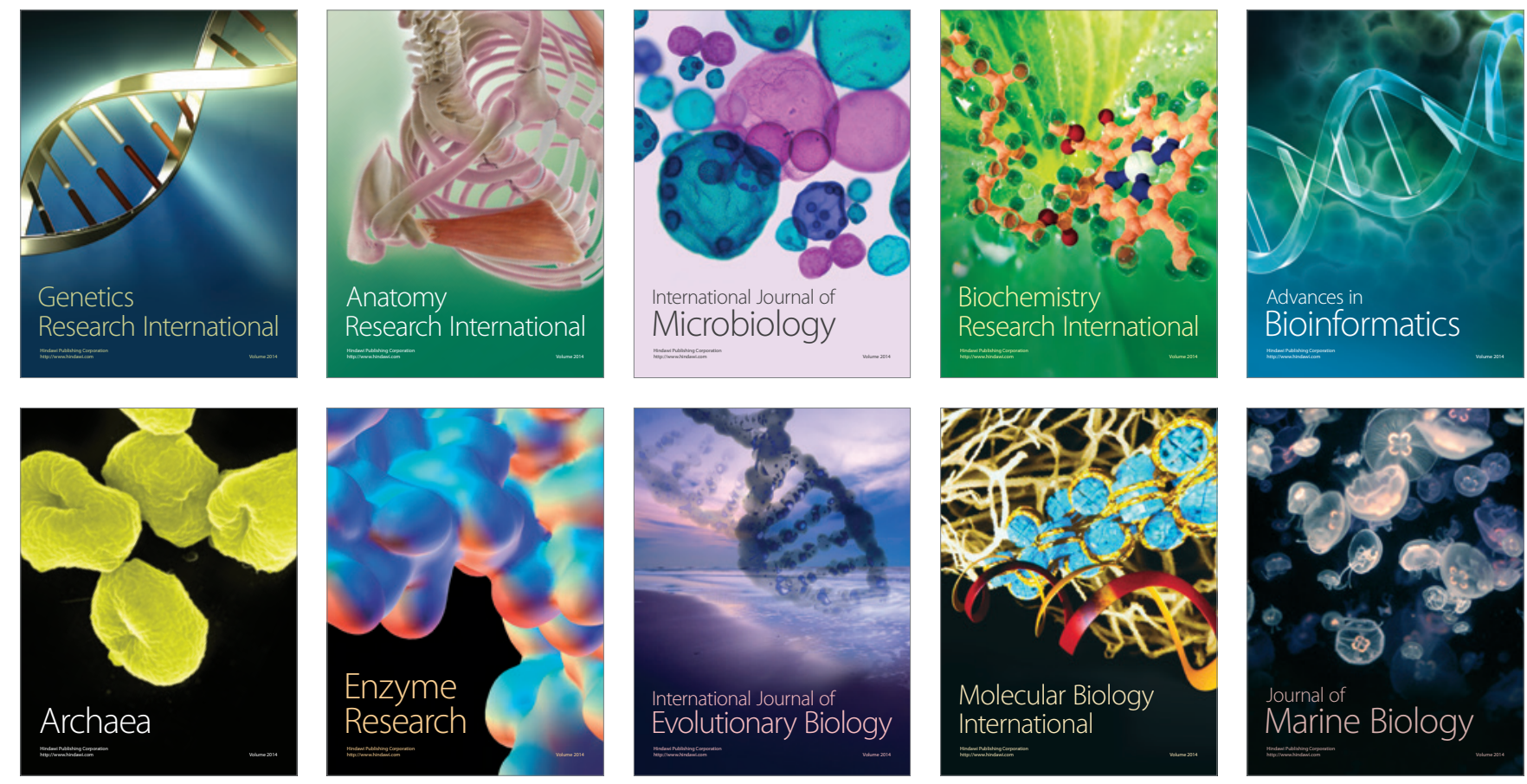